\title{
Private Actors, Public Goods and Responsibility for the Right to Water in International Investment Law: An Analysis of Urbaser v. Argentina
}

\author{
Edward Guntrip \\ University of Sussex \\ e.j.guntrip@sussex.ac.uk
}

\begin{abstract}
International investment law balances public and private interests within the broader framework of international law. Consequently, when water supply services, which constitute a public good, are privatized and operated by foreign investors, questions arise regarding whether foreign investors could be held responsible for the right to water under international law. This article considers how the tribunal in Urbaser v. Argentina allocated responsibility for compliance with the right to water between the host State and the foreign investor when resolving a dispute over privatized water services. It highlights how the tribunal in Urbaser v. Argentina supports different understandings of public and private based on whether the human rights obligation is framed in terms of the duty to respect or protect. The article argues that the tribunal's rationale overcomplicates the process of allocating responsibility for violations of the human right to water when water supply services have been privatized.
\end{abstract}

\section{Keywords}

international human rights law -international investment law -investment arbitration - privatization - right to water

\footnotetext{
* This article is based on a paper presented at the Workshop of the Interest Group on International Economic Law of the European Society of International Law devoted to 'Global Public Goods, Global Commons, Fundamental Values: The Responses of International Economic Law', held in Naples on 6 September 2017.
}

(C) GUNTRIP, 2018 | DOI 10.1163/23527072-00101004

This is an open access article distributed under the terms of the prevailing CC-BY License at the time of publication. 
International investment law (IIL) blends concepts of public and private. ${ }^{1}$ The merger of these notions in IIL is illustrated by some of the public/private interactions that arise when water supply and sanitation services are privatized and operated by foreign investors. In this setting, privatization results in a private foreign investor supplying the host State population with water, which traditionally constituted a public service. ${ }^{2}$ From a legal perspective, privatization is governed by private obligations sourced from domestic law. ${ }^{3}$ Yet, a foreign investor's private property rights are protected by principles of IIL, which are sourced from public international law. ${ }^{4}$ As a result of the privatization of water supply services, private foreign investors can effect whether the local population enjoys the human right to water, ${ }^{5}$ a right sourced from public international law. ${ }^{6}$ These intersections between public and private generate tensions within IIL given the competing policy objectives underpinning each interaction.

The tensions that result from the various interactions between public and private crystallize when investment disputes arise over water supply and sanitation services. It lies with the investment tribunal to evaluate the degree to

1 See Julie A. Maupin, 'Public and Private in International Investment Law: An Integrated Systems Approach', Virginia Journal of International Law, 54/2: 367-435 (2014); Alex Mills, 'Antinomies of Public and Private at the Foundations of International Investment Law and Arbitration', Journal of International Economic Law, 14/2: 469-503 (2011).

2 Fernando Dias Simões, 'The Erosion of the Concept of Public Service in Water Concessions: Evidence from Investor-State Arbitration' in Julien Chaisse (ed.), The Regulation of the Global Water Services Market (Cambridge: Cambridge University Press, 2017), p. 71.

3 Ibid., p. 79.

4 See José E. Alvarez, The Public International Law Regime Governing International Investment (The Hague: Hague Academy of International Law, 2011).

5 Markus Krajewski, 'Protecting the Human Right to Water through the Regulation of Multinational Enterprises' in Julian Chaisse (ed.), The Regulation of the Global Water Services Market (Cambridge: Cambridge University Press, 2017), p. 167.

6 The International Covenant on Economic, Social and Cultural Rights does not contain an express right to water. However, the Committee on Economic, Social and Cultural Rights recognized the right in General Comment No. 15; UN Committee on Economic, Social and Cultural Rights (CESCR), General Comment No. 15: The Right to Water (Arts. 11 and 12 of the Covenant), E/C.12/2002/1, 20 January 2003. See Paula Gerber and Bruce Chen, 'Recognition of the Human Right to Water: Has the Tide Turned?', Alternative Law Journal, 36/1: 21-26 (2011); Stephen Tully, 'A Human Right to Access Water? A Critique of General Comment No. 15', Netherlands Quarterly of Human Rights 23/1: 35-63 (2005). 
which public and private interests conflict and to reconcile the legal standards and frameworks that apply. Investment tribunals regularly resolve disputes by doing exactly this. However, investment tribunals frequently overlook the significance of human rights obligations in disputes over water supply services, ${ }^{7}$ and in so doing, fail to address a key public dimension of the dispute. The reluctance of investment tribunals to fully engage with the human right to water could be due to the distinct legal structure that governs human rights obligations. Under the human rights framework, States have traditionally borne responsibility for compliance with human rights obligations. ${ }^{8}$ For economic, social and cultural rights, which include the right to water, this obligation has been further broken down by the UN Committee on Economic, Social and Cultural Rights (CESCR) into obligations to respect, protect and fulfil. ${ }^{9}$ Hence, States must not interfere with the enjoyment of the right (the duty to respect), ${ }^{10}$ give effect to and support the right by preventing third parties from infringing the right (the duty to protect $)^{11}$ and take necessary action to ensure the right is enjoyed (the duty to fulfil). ${ }^{12}$ Under this framework, the State is ultimately responsible for all types of human rights violations, leaving little room for investment tribunals to hold private actors responsible for breaches of human rights standards. Nonetheless, when water supply and sanitation services have

Tribunals have recognized the relevance of the right to water to disputes regarding water supply services, but have failed to fully address its significance. See, for example, SAUR International s.A. v. Argentine Republic, ICSID Case No. ARB/04/4, Decision on Jurisdiction and Liability, 6 June 2012, paras. 330-331.

See Adam McBeth, International Economic Actors and Human Rights (Abingdon: Routledge, 2010), pp. 11-15.

9 The CESCR has applied this framework since General Comment No. 12; CESCR, General Comment No. 12: The Right to Adequate Food (Art. 11 of the Covenant), E/C.12/1999/5, 12 May 1999 .

$10 \quad$ Frédéric Mégret, 'Nature of Obligations' in Daniel Moeckli, Sangeeta Shah and Sandesh Sivakuraman (eds.), International Human Rights Law (Oxford: Oxford University Press, 2010), p. 130; Gilles Giacca, Christophe Golay, and Eibe Riedel, 'The Development of Economic, Social, and Cultural Rights in International Law' in Eibe Riedel, Gilles Giacca, and Christophe Golay (eds.), Economic, Social, and Cultural Rights in International Law: Contemporary Rights in International Law (Oxford: Oxford University Press, 2014), p. 18; Christian Tomuschat, Human Rights: Between Idealism and Realism (Oxford: Oxford University Press, 2014), p. 142.

11 Mégret, supra note 10, pp. 130-131; Giacca, Golay, and Riedel, supra note 10, p. 19; Tomuschat, supra note 10, p. 142.

12 Mégret, supra note 10, p. 131; Giacca, Golay, and Riedel, supra note 10, p. 19; Tomuschat, supra note 10, p. 142. 
been privatized, the foreign investor plays an instrumental role in determining whether the host State population enjoys the right to water. ${ }^{13}$ Given that the foreign investor is so influential, there is discussion regarding whether foreign investors should be directly bound by human rights obligations. However, to implement this proposal, adjustments to the State-based respect, protect and fulfil framework would be required because it is not currently structured in a way that accommodates non-State actors as duty bearers.

Urbaser v. Argentina ${ }^{14}$ (Urbaser) is the most recent award to address an investment dispute regarding a privatized water supply and sanitation service. Significantly, it is the first award to directly examine the application of the human right to water to this type of dispute. As such, the Urbaser award provides an insight into how investment tribunals might address the public interest in the form of human rights obligations. The reasoning of the tribunal challenges the existing human rights structures to create a binding obligation for non-State actors to respect the right to water. ${ }^{15}$ This article argues that, when creating this obligation, the tribunal in Urbaser utilizes different understandings of public and private based on whether the right to water is framed in terms of an obligation to respect or to protect. By taking this approach, the tribunal overcomplicates the process of allocating responsibility for compliance with the human right to water in instances where water and sanitation services have been privatized. To establish this position, this article focuses its discussion around the process of privatization, which captures the blending of public and private in IIL. It refers to the privatization of water supply and sanitation services to identify three understandings of public and private that apply in this context. The host State's counterclaim in the Urbaser award is then analyzed from the perspective of how the tribunal manages to reconcile these three forms of public and private in its reasoning. This highlights how the tribunal applies contradictory understandings of public and private when addressing the obligations to respect and to protect respectively. The article then considers some of the implications of the distinction made by the tribunal between the obligations to respect and to protect, with reference to the apportionment of international responsibility for compliance with the human right to water.

\footnotetext{
13 Krajewski, supra note 5, p. 167.

14 Urbaser s.A. and Consorcio de Aguas Bilbao Biskaia, Bilbao Biskaia Ur Partzuergoa v. Argentine Republic, ICsID Case No. ARB/o7/26, Award, 8 December 2016 (hereinafter Urbaser v. Argentina).

15 Ibid., para. 1199.
} 


\section{Privatization and Understandings of Public and Private}

In general terms, privatization occurs when those who represent the public sector transfer responsibility for certain activities from the public sector to the private sector. ${ }^{16}$ Privatization can take various forms: ${ }^{17}$ States can sell public assets outright; retain title to assets but cease to manage them; or lease control of public assets to private actors for a period of time. ${ }^{18}$ Consequently, what amounts to privatization in any given situation will differ. ${ }^{19}$ However, at its essence, privatization focuses on the legal relationship between public and private interests. In the context of privatized water supply and sanitation services, there are three interactions between public and private that are relevant to understanding the Urbaser award. First, the status and role of each actor is examined with reference to how concession contracts are used to privatize public services. Second, public and private approaches to water are discussed in light of the philosophies that determine how water should be distributed. Finally, the protection of public and private legal interests are considered by analyzing the interrelationships between the applicable legal frameworks that govern privatized water supply services and the human right to water.

\subsection{Concession Contracts}

The dominant means of achieving privatization in the water sector is through the use of concession contracts. ${ }^{20}$ Concession contracts govern the legal relationship that arises when a State, as a public entity, transfers some of its public functions to a private actor, which in the context of IIL is a foreign investor. ${ }^{21}$ As such, concession contracts focus on the status and function of the actors involved in the privatization process. The status and role of each actor provides the first iteration of how public and private can be understood in the context of privatized water supply services. Under most water concessions, the State retains legal ownership of the water supply and sanitation service, but the

16 Lennart J. Lundqvist, 'Privatization: Towards a Concept for Comparative Policy Analysis', Journal of Public Policy, 8/1: 1-19 (1988), p. 12.

17 David Heald, 'Privatisation: Analysing its Appeals and Limitations', Fiscal Studies, 5/1: 36-46 (1984), p. 45 .

18 Khulekani Moyo, 'Privatisation of the Commons: Water as a Right; Water as a Commodity', Stellenbosch Law Review, 22: 804-822 (2011), p. 812.

19 Ibid.; Lundqvist, supra note 16, p. 2.

$20 \quad$ Simões, supra note 2, p. 71.

21 Moyo, supra note 18, p. 812. 
private actor provides operational and managerial functions ${ }^{22}$ that generate income. As a result, private actors bear the financial risk. ${ }^{23}$ The State is usually responsible for billing customers and for undertaking some regulatory activities such as monitoring unfair trading and ensuring customer needs are met. ${ }^{24}$ Consequently, the State's involvement in the provision of the public service is significantly reduced, ${ }^{25}$ but it is not completely absolved of all responsibility in relation to the privatized water service. Therefore, concession contracts create a working distinction between the State as a public body and the foreign investor as a private actor. However, given the interrelated nature of the roles that each actor performs, concession contracts do not strictly delineate between the concepts of public and private. ${ }^{26}$

\section{$2.2 \quad$ Access to Water}

The privatization of water supply and sanitation services has given rise to competing philosophies regarding how water should be distributed. These opposing outlooks produce a second understanding of public and private. Water has traditionally been considered to be a public resource. ${ }^{27}$ By placing water supply and sanitation services under the control of the private sector, water becomes a commodity. ${ }^{28}$ This is because, under this structure, access to water is usually based on the ability to pay, rather than being a freely accessible resource. When water is viewed as an asset, a private perspective is adopted. From one viewpoint, the private approach is beneficial because it provides an efficient means of distributing a limited resource. ${ }^{29}$ By requiring consumers

22 Khulekani Moyo and Sandra Liebenberg, 'The Privatization of Water Services: The Quest for Enhanced Water Rights Accountability', Human Rights Quarterly, 37/3: 691-727 (2015), p. 695; Simões, supra note 2, p. 71.

23 Julien Chaisse and Marine Polo, 'Globalization of Water Privatization: Ramifications of Investor-State Disputes in the "Blue-Gold" Economy', Boston College International and Comparative Law Review, 38/1: 1-63 (2015), p. 8; Simões, supra note 2, p. 71.

24 Chaisse and Polo, supra note 22, p. 9.

25 Moyo and Leibenberg, supra note 22, p. 692.

26 Gillian E. Metzger, 'Privatization as Delegation', Columbia Law Review, 103/6: 1367-1502 (2003), p. 1370.

27 Jennifer Naegele, 'What is Wrong with Full-Fledged Water Privatization?', Journal of Law and Social Challenges, 6: 99-130 (2004), p. 100.

28 Moyo, supra note 18, p. 812.

29 Craig Macklin and Carolan Mclarney, ‘Too Public Not To Be Private: Investigating Water Ownership as a Strategy in a World of Economic Goods Under International Trade and Investment Laws', IUP Journal of Business Strategy, 11/1: 7-22 (2014), p. 13; Naegele, supra note 27, p. 100; Fabrizio Marrella, 'On the Changing Structure of International Investment 
to pay market price for water, they will only use what they need, thereby conserving the resource. ${ }^{30}$ Further, private capital can expand water supply systems and thereby increase access to water, ${ }^{31}$ although, this may be at a greater expense for the recipient of the water. ${ }^{32}$ However, a market driven approach to water supply does not necessarily take into account equitable access to water. ${ }^{33}$ Consequently, an alternative standpoint emphasizes the fundamental nature of water for human existence and does not view water as a commodity, but stresses equal access to water as a fundamental human right. ${ }^{34}$ Based on this understanding, water should be available to all regardless of cost. ${ }^{35}$ This position reflects a public perspective regarding access to water. In practice, the distinctions drawn between public and private approaches to access to water are not definitive. ${ }^{36}$ This is because both public and private stances operate in tandem to manage the tension that arises from water being a limited resource that also provides a fundamental human need. Nonetheless, the philosophies underpinning each viewpoint correlate with understandings of public and private.

\subsection{Legal Framework}

The legal framework that governs privatized water and sanitation services provides the third example of how the concepts of public and private interrelate. Legal systems can be classified in a variety of ways depending on what attributes of the legal system are prioritized. Consequently, the analysis presented in this section provides only one limited perspective. Although the approach set out below is contestable, the interpretation put forward assists with understanding how the tribunal in Urbaser reached its conclusion.

Both domestic law and international law apply to privatized water supply and sanitation services. Concession contracts determine the relationship between the public and private sectors under domestic law by allocating responsibilities between the foreign investor and the host State for the running of

Law: The Human Right to Water and ICsid Arbitration', International Community Law Review, 12/3: 335-359 (2010), p. 336.

$30 \quad$ Naegele, supra note 27, p. 101.

31 Ibid., p. 107; Simões, supra note 2, p. 70.

32 Macklin and Mclarney, supra note 29, p. 14.

33 Naegele, supra note 27, p. 101; Moyo, supra note 18, p. 814.

34 See CESCR, General Comment No. 15, supra note 6, para. 2. Naegele, supra note 27, p. 101; Moyo, supra note 18, p. 805; Marrella, supra note 29, p. 336.

35 Macklin and Mclarney, supra note 29, p. 9.

36 Bronwyn Morgen, Water on Tap: Rights and Regulations in the Transnational Governance of Urban Water Services (Cambridge: Cambridge University Press, 2011), p. 2. 
the privatized water supply and sanitation service. ${ }^{37}$ By conferring the foreign investor with rights and obligations, the domestic contract creates private legal interests. At the international level, the foreign investor's property rights associated with the privatized water supply, which potentially include rights contained in the concession contract, are protected by international investment agreements (IIAS) and customary IIL. ${ }^{38}$ Thus, although IIL binds States, it also supports the private aspects of the legal relationship between the State and the foreign investor. A tension arises within this framework, because whilst both concession contracts and IIL seek to protect private rights, they use private, domestic law and public international law respectively to achieve this aim.

This position can be contrasted with the law governing the right to water, which can be classified as being solely public in nature. This is because, in part, the right to water promotes the idea of access to water for all. ${ }^{39}$ However, in addition, the right to water is sourced from international human rights law and only binds States. ${ }^{40}$ As foreign investors lack international legal personality, in accordance with traditional understandings of public international law, they cannot owe obligations under international law. ${ }^{41}$ Hence, States retain the legal obligation in public international law to ensure that the human right to water is fulfilled even though the private actor is providing the water supply service..$^{42}$ Non-binding soft law instruments such as the Guiding Principles on Business and Human Rights ${ }^{43}$ and voluntary initiatives such as the UN Global Compact ${ }^{44}$ have sought to encourage private corporate bodies (including foreign investors) to comply with obligations sourced from international human rights law in the absence of binding legal obligations. ${ }^{45}$

37 Simões, supra note 2, p. 71.

38 Ursula Kriebaum, 'Privatising Human Rights: The Interface between International Investment Protection and Human Rights' in August Reinisch and Ursula Kriebaum (eds.), The Law of International Relations - Liber Amicorum Hanspeter Neuhold (Utrecht: Eleven International Publishing, 2007), p. 186; Morgen, supra note 36, p. 175 .

39 See CESCR, General Comment No. 15, supra note 6, para. 2.

40 Markos Karavias, 'Shared Responsibility and Multinational Enterprises', Netherlands International Law Review, 62: 91-117 (2015), p. 101.

$41 \quad$ Naegele, supra note 27, p. 118.

42 Moyo, supra note 18, p. 818; Kriebaum, supra note 38, p. 166.

43 Office of the High Commissioner of Human Rights, Guiding Principles on Business and Human Rights: Implementing the United Nations 'Protect, Respect and Remedy' Framework, HR/PUB/11/04, January 2012. UN Global Compact, http://www.unglobalcompact.org.uk, accessed 10 April 2018.

45 See Nadia Bernaz, Business and Human Rights: History, Law and Policy - Bridging the Accountability Gap (Abingdon: Routledge, 2016), pp. 163-203. 
There is very little intersection between the domestic and international legal frameworks that address the public and private aspects of privatized water supply services. Concession contracts are governed by domestic law and rarely refer to international obligations ${ }^{46}$ and international human rights law does not directly address private actors. Further, IIAs seldom fully set out how investment protection standards interrelate with legal obligations sourced from other regimes in international law. ${ }^{47}$ Therefore, the right to water is protected on the international plane, but it operates independently of the concession contract, any applicable IIA and customary IIL. Hence, neither the domestic or international legal planes enable both public and private interests to be accommodated in the context of privatized water supply services. This legal framework creates an unusual position for both foreign investors and States when addressing the public aspects of privatized water supply services because 'foreign private investors found themselves involved in activities with a clear impact on human rights obligations incumbent upon States. Conversely, States overlooked the fact that by privatizing certain essential services there would have been no transfer of international responsibility in terms of human rights obligations. ${ }^{48}$

Consequently, there are different understandings of public and private in the legal framework governing privatized water supply and sanitation services. Private interests are set out in domestic law in the form of concession contracts and are supported by IIL. As IIL relies on public international law to protect private interests, notions of public and private converge. Law that seeks to protect public goods, such as water, usually operates on the international plane. There is a disconnect between public and private within this legal framework as the law that seeks to protect private interests rarely operates in conjunction with the law that seeks to protect public interests, either on the international plane, or between the applicable domestic and international legal frameworks.

\subsection{Preliminary Conclusion}

In short, privatizing water supply and sanitation services in the context of IIL generates multiple understandings of the concepts of public and private. This section has drawn attention to three conceptualizations. These relate to the status of the actors involved, the basis on which water is allocated and the legal

\footnotetext{
46 Eric de Brabandere, Investment Treaty Arbitration as Public International Law: Procedural Aspects and Implications (Cambridge: Cambridge University Press, 2014), p. 30.

47 A rare exception is Article 18 of the Morocco-Nigeria Bilateral Investment Treaty (not yet in force) that sets out human rights obligations for foreign investors.

48 Marrella, supra note 29, p. 348.
} 
frameworks that govern these relationships. Although not definitive, the classifications discussed above illustrate the tensions that the tribunal in Urbaser was attempting to resolve. As such, they provide a useful frame of reference for analyzing the Urbaser award.

The Urbaser award is the latest investment award to address a dispute over privatized water supply services. ${ }^{49}$ The claimant in the dispute was a shareholder in a corporate concessionaire that supplied water and sewerage services in Buenos Aires. ${ }^{50}$ Following Argentina's financial crisis in 2001-2, Argentina enacted emergency measures that exacerbated the concession's financial difficulties. ${ }^{51}$ After the concessionaire had become insolvent, the claimant commenced arbitral proceedings against Argentina for violations of the SpainArgentina bilateral investment treaty (Spain-Argentina BIT). ${ }^{52}$ Argentina counterclaimed, based on the concessionaire's failure to provide the necessary level of investment in the concession, which it claimed, led to violations of the human right to water. ${ }^{53}$

Argentina's counterclaim is particularly instructive with regards to how the tribunal understands the intersections between public and private in the context of privatized water supply and sanitation services. This is because the tribunal's discussion of the counterclaim directly addresses how the right to water applies to foreign investors who operate privatized water supply services. The tribunal's analysis in relation to the counterclaim proceeds in three stages. First, it discusses the general human rights obligations of corporations. Second, it considers the legal obligations associated with the human right to

49 Previous awards include SAUR International s.A. v. Argentine Republic, ICSID Case No. ARB/04/4, Decision on Jurisdiction and Liability, 6 June 2012; Azurix Corp. v. Argentine Republic, ICSID Case No. ARB/01/12, Award, 14 July 2006 (and annulment proceedings, Azurix Corp. v. the Argentine Republic, ICSID Case No. ARB/o1/12, Decision on the Application for Annulment of the Argentine Republic, 1 September 2009); Suez, Sociedad General de Aguas de Barcelona s.A. and Interagua Servicios Integrales de Agua s.A. v. Argentine Republic, ICSID Case No. ARB /03/17, Decision on Liability, 30 July 2010; and Suez, Sociedad General de Aguas de Barcelona s.A. and Vivendi Universal S.A v. Argentine Republic, ICSID Case No. ARB/03/19, Decision on Liability, 30 July 2010.

5o Urbaserv. Argentina, para. 34.

$51 \quad$ Ibid.

$5^{2} \quad$ Ibid., para. 35 .

53 Ibid., paras. $36-37$. 
water. Finally, it examines the legal relationship between the foreign investor and Argentina to determine whether these obligations bind the claimant in this case.

\subsection{Human Rights Obligations and Corporations}

At the commencement of its analysis, the tribunal immediately opposes the contention that 'guaranteeing the human right to water is a duty that may be born solely by the State. ${ }^{54}$ In so doing, the tribunal rejects the notion that corporations are not subjects of international law on the basis that such a principle 'has lost its impact and relevance. ${ }^{55}$ With indirect reference to the Ruggie Report, ${ }^{56}$ the tribunal explains that corporate social responsibility requires corporations to conduct their operations in a manner that complies with human rights. ${ }^{57}$ The tribunal acknowledges that, whilst corporations are not immune from becoming subjects of international law, this does not necessarily result in the creation of human rights obligations that directly bind corporate bodies. ${ }^{58}$ To ensure that companies are subject to appropriate obligations 'the focus must be, therefore, on contextualizing a corporation's specific activities as they relate to the human right at issue in order to determine whether any international law obligations attach to the non-State individual.'59

In the first stage of the tribunal's reasoning, focus is placed on the actors involved in privatized water supply services and the legal framework that applies to them. By identifying that the fulfilment of the human right to water is not solely an obligation of the State, the tribunal indicates that public international law has the potential to bind foreign investors in addition to States. By taking this position, the tribunal disregards the traditional view that non-State actors are only governed by domestic law and States by public international law. ${ }^{60}$ As such, the tribunal blends understandings of public and private. Merging

\footnotetext{
$54 \quad$ Ibid., para. 1193 .

55 Ibid., para. 1194.

56 UN Human Rights Council, Protect, Respect and Remedy: a Framework for Business and Human Rights: Report of the Special Representative of the Secretary-General on the Issue of Human Rights and Transnational Corporations and Other Business Enterprises, John Ruggie, A/HrC/8/5, 7 April 2008.

57 Urbaserv. Argentina, para. 1195.

58 Ibid.

59 Ibid.

6o Cedric Ryngaert, 'Imposing International Duties on Non-State Actors and the Legitimacy of International Law' in Math Noortmann and Cedric Ryngaert (eds.), Non-State Actor Dynamics in International Law: From Law-Takers to Law-Makers (Abingdon: Routledge, 2010), p. 78 .
} 
public and private in this way is contrary to the position that international human rights law only binds States, and consequently, fundamentally alters how international human rights law functions.

\subsection{Corporations and the Right to Water}

In the second phase, to contextualize the obligations of the corporate foreign investor, the tribunal examined the nature of obligations relating to the human right to water. Based on the terminology adopted in the Universal Declaration on Human Rights (UDHR), ${ }^{61}$ the tribunal acknowledged that individuals are not bound by its terms, but for the UDHR to be effective, individuals must contribute to the fulfilment of the obligations contained in the UDHR. ${ }^{62}$ These obligations include the right to equal access to public service (Article 21(2) UDHR) and the right to a standard of living adequate for health and well-being (Article 25(1) UDHR), both of which the tribunal deems are capable of encompassing access to a clean, public water supply. ${ }^{63}$ The tribunal additionally drew support for the view that non-State actors contribute to human rights compliance from Article 5(1) of the International Covenant on Economic, Social and Cultural Rights $^{64}$ (ICESCR). ${ }^{65}$ This provision precludes rights contained in the ICESCR from being interpreted in a manner that permits States and non-State actors to destroy or limit other rights set out in the ICESCR. The tribunal referred to General Comment No. 15 of CESCR to support the position that the ICESCR encompasses the right to water. ${ }^{66}$ Further support for the right to water was drawn from the United Nations' General Assembly Resolution 64/292. ${ }^{67}$ Final$\mathrm{ly}$, the tribunal referred to the requirement that corporations respect the UDHR and the ICESCR, which it sourced from Article 8 of the International Labor Office's Tripartite Declaration of Principles concerning Multilateral Enterprises and Social Policy (of 1977, as amended in 2006). ${ }^{68}$ Based on these instruments,

\footnotetext{
61217 A(III), 10 December 1948 (UDHR).

62 Urbaserv. Argentina, para. 1196.

63 Ibid.

641976 International Covenant on Economic, Social and Cultural Rights (ICSECR) (signed 16 December 1966; entered into force 3 January 1976), UNTS 993: 3.

65 Urbaserv. Argentina, para. 1197.

66 Ibid.

67 Ibid.; A/REs/64/292, 3 August 2010.

68 Urbaser v. Argentina, para. 1198; ILO, 'Tripartite Declaration of Principles concerning Multilateral Enterprises and Social Policy', adopted by the Governing Body of the International Labour Office at its $204^{\text {th }}$ Session, http://www.ilo.org/wcmsp5/groups/public/--ed_emp/---emp_ent/---multi/documents/publication/wcms_094386.pdf, accessed 10 April 2018. This version includes the March 2017 updates.
} 
the tribunal found that in addition to human rights giving effect to the right to water, there was also 'an obligation on all parts, public and private parties, not to engage in activity aimed at destroying such rights. ${ }^{69}$

In its second stage of analysis, the tribunal introduces a binding legal obligation for non-State actors in relation to the right to water. By focusing on not destroying the enjoyment of the right to water, the foreign investor's obligation is framed in terms that mirror the State obligation to respect the human right to water ${ }^{70}$ (which continues to apply). The foreign investor's obligation to respect the right to water emphasizes water as a public good that satisfies a human need. This operates in addition to the private understanding of water as a commodity, which the foreign investor is already bound by under the concession contract. Thus, the tribunal merges the public viewpoint on access to water with a private approach, thereby requiring the foreign investor to balance both philosophies that underlie the debate over access to water. To achieve this result, the tribunal bridged the domestic and international legal frameworks. The tribunal found textual foundations in the relevant international instruments that permit international obligations to directly bind non-State actors, such as foreign investors. The tribunal's conclusion is controversial, as Article 5(1) ICESCR does not create substantive obligations for parties to the ICESCR. ${ }^{71}$ Further, Article 21(2) UDHR is commonly understood as referring to the right to equal employment opportunities within a State's public or civil service, ${ }^{72}$ rather than relating to the provision of public services such as water supply and sanitation services. Hence, the tribunal prioritizes public approaches to access to water and undertakes an unorthodox analysis of the legal instruments

69 Urbaserv. Argentina, para. 1199.

70 See Anil Yilmaz-Vastardis, 'Is International Investment Law moving the ball forward on IHRL obligations for business enterprises?', EJIL Talk!, 15 May 2017, https://www.ejiltalk. org/is-international-investment-law-moving-the-ball-forward-on-ihrl-obligations-for -business-enterprises/, accessed 10 April 2018.

71 For discussion regarding the use of Article 5(1) ICESCR in this way, see Edward Guntrip, 'Urbaser $v$ Argentina: The Origins of a Host State Human Rights Counterclaim in ICSID Arbitration?' EJIL Talk!, 10 February 2017, https://www.ejiltalk.org/urbaser-v-argentina -the-origins-of-a-host-state-human-rights-counterclaim-in-icsid-arbitration/, accessed 10 April 2018.

72 See Un Human Rights Committee (HRC), CCPR General Comment No. 25: Article 25 (Participation in Public Affairs and the Right to Vote), The Right to Participate in Public Affairs, Voting Rights and the Right of Equal Access to Public Service, CCPR/C/21/Rev.1/Add.7, 12 July 1996, para. 23, which addresses Article 25(c) of the 1966 International Covenant on Civil and Political Rights (signed 16 December 1966; entered into force 23 March 1976) UNTS 999: 171, which is phrased in similar terms to Article 21(2) of the UDHR. 
regulating public and private interests. In so doing, it merges public and private, with the result that, in addition to the State, the foreign investor is legally bound by the duty to respect the right to water.

\subsection{Corporate Obligations and the Claimant}

Finally, having determined that the Spain-Argentina BIT and the Washington Convention ${ }^{73}$ permitted reference to international human rights law, ${ }^{74}$ the tribunal proceeded to examine the specific nature of the foreign investor's obligation in this instance. Whilst recognizing the right to water as part of international human rights law, ${ }^{75}$ the tribunal proceeded to consider whether this human right amounted to a binding legal obligation on the claimant. The tribunal referred to how Argentina constructed its counterclaim, and in particular, the failure of Argentina to specify the precise legal foundation of the foreign investor's obligation other than the general performance of the concession contract. ${ }^{76}$ This was problematic because 'the human right to water entails an obligation of compliance on the part of the State, but it does not contain an obligation for performance on part of any company providing the contractually required service. ${ }^{77}$

The source of the foreign investor's alleged legal obligation underpins the tribunal's reasoning from this point. The tribunal deems that, for obligations based on the human right to water to apply to a company, a contractual or commercial legal relationship is required. ${ }^{78}$ This is to be sourced from domestic law and not general international law. ${ }^{79}$ In the absence of any obligation on the foreign investor, and Argentina's involvement in the regulation of the water supply, Argentina bore responsibility for complying with the human right to water. ${ }^{80}$

In the final stage of the tribunal's discussion of Argentina's counterclaim, the tribunal continues to address the right to water, but emphasizes a separate aspect of the right. The use of language such as 'performance' stresses an obligation to give effect to the right, thereby framing this discussion in terms of the obligation to protect. ${ }^{81}$ The tribunal's position during the third stage of its

\footnotetext{
731966 Convention on the Settlement of Investment Disputes Between States and Nationals of Other States (signed 18 March 1965; entered into force 14 October 1966), UNTS 575: 159.

74 Urbaserv. Argentina, paras. 1201-1203.

75 Ibid., para. 1205 .

76 Ibid., para. 1206.

77 Ibid., para. 1208.

78 Ibid., para. 1210.

79 Ibid.

8 Ibid., para. 1213 .

81 See Yilmaz-Vastardis, supra note 70.
} 
analysis is clearly influenced by both its jurisdictional limits and the manner in which Argentina formulated the terms of its counterclaim. Nonetheless, the tribunal takes the opposite stance to that outlined in relation to the obligation to respect. This is evidenced by how the tribunal applies the concepts of public and private in this section of its award. When discussing the obligation to protect, the tribunal stresses that only States are bound by obligations sourced in public international law and requires the human right to water be incorporated into contractual terms, or domestic law provisions, in order for it to bind foreign investors. ${ }^{82}$ Thus, the tribunal views the foreign investor as a private actor that can only be regulated by private, domestic law and States as public actors that can only be regulated by public international law. This is in contrast to the second stage of the tribunal's discussion, where it found a textual basis for bridging the private and public aspects of the same legal framework.

By distinguishing between the public and private aspects of the legal framework when addressing the obligation to protect, the tribunal also segregates public and private understandings relating to access to water. The foreign investor continues to operate under the private framework of the concession contract where water is a commodity. However, as the foreign investor is not bound by a direct obligation under international law to protect the right to water, enabling access to water in the form of a public good remains the sole responsibility of the State. This position contrasts with the obligation to respect where the foreign investor must balance the public and private justifications underpinning access to water.

When the obligations to respect and to protect are analyzed by reference to the conceptualizations of public and private outlined in the section above, it becomes clear that the tribunal in Urbaser views the nature of these obligations very differently. The obligation to respect the right to water is binding on States and foreign investors regardless of the legal framework that governs the privatization relationship or any distinction that is drawn between public and private. In contrast, the duty to protect binds States under international law, but whether it additionally binds foreign investors depends on whether the legal obligation can be sourced from domestic law. In taking this stance, the tribunal clearly separates public and private.

\subsection{Preliminary Conclusion}

In conclusion, the Urbaser award utilizes three understandings of public and private that arise when water supply and sanitation services are privatized by foreign investors. These conceptions are based on the actors involved in the

$82 \quad$ Urbaserv. Argentina, para. 1210. 
privatization process, the basis on which water should be distributed and the legal framework that governs privatized water supply services. When addressing whether corporate foreign investors could be bound by international law, and establishing that there was a duty on States and foreign investors to respect (i.e. not destroy) the human right to water, the tribunal merged all three concepts of public and private. However, when discussing the duty to protect (i.e. to give effect to) the human right to water, the tribunal reverted to traditional understandings and legal frameworks that distinguish between public and private. By taking varied approaches based on whether the obligation is to respect or to protect, and allocating differentiated duties to States and non-State actors accordingly, the tribunal raises questions regarding the allocation of international responsibility for the human right to water when water and sanitation services have been privatized and are operated by foreign investors.

The Urbaser award holds different actors responsible for compliance with the right to water under international law based on whether the obligation is to respect or to protect. In relation to the obligation to protect (i.e. to give effect to) the right to water, the State is responsible under international law and must use domestic legal frameworks to transfer responsibilities to a foreign investor. This structure aligns with classic understandings of how international human rights law should be implemented. ${ }^{83}$ With regards to the obligation to respect (i.e. not destroy) the right to water, the tribunal finds that the host State and the foreign investor may both be held responsible under international law for conduct that destroys enjoyment of the right to water. This framework does not conform to traditional understandings of how international human rights law functions, and as such, raises questions regarding the workability of this distinction. The implications of the Urbaser award adopting divergent approaches to the obligations to respect and to protect the right to water will be analyzed, first, by reference to the tribunal's use of the respect, protect and fulfil framework to establish these differentiated obligations, and second, by considering how a foreign investor can be found responsible within the existing State-based respect, protect and fulfil framework. Throughout this discussion, focus is placed on the international responsibility of the foreign investor as it is this form of responsibility that is contentious.

83 This forms part of the State's duty to protect. 


\subsection{Allocating Responsibility between States and Non-State Actors}

The Urbaser award draws a crucial distinction between obligations to respect the right to water and obligations to protect the same right. The classification of the obligation determines whether a foreign investor can be held to be internationally responsible for compliance with the right to water. The Urbaser tribunal's allocation of responsibility between States and non-State actors based on obligations to respect and protect can be justified, to a certain extent, by reference to the degree of influence that States and non-States actors are able to exert over other actors. International human rights law classically binds States because they possess the power to violate human rights. ${ }^{84}$ The obligation to respect requires States to refrain from using their power to breach human rights standards. As a corollary, States also have the power to prevent third parties from committing human rights violations. ${ }^{85}$ States can exercise this power by, for example, enacting domestic legislation to regulate conduct within their territory. ${ }^{86}$ As the State is conferred with the power required to bind others, the obligation to protect is most effectively performed by the State. Therefore, States are able to comply with the duties to respect and to protect. In contrast, non-State actors' powers are primarily limited to controlling their own conduct (which includes their business relations). ${ }^{87}$ As such, any obligation imposed upon non-State actors should focus on ensuring that their individual conduct is in compliance with human rights standards. In this regard, the most appropriate obligation for a non-State actor is one that mirrors the State's duty to respect. This model has been employed in soft law instruments such as the Guiding Principles on Business and Human Rights. ${ }^{88}$ Therefore, the tribunal in Urbaser assigns the most pertinent obligations to each actor from the perspective of their respective spheres of influence.

However, there is a significant difference between seeking to maximize compliance with human rights obligations by targeting the powers of specific

84 Andrew Fagan, Human Rights: Confronting Myths and Misunderstandings (Cheltenham: Edward Elgar Publishing, 2009), p. 91.

85 Biagio Zammitto, 'The Duty to Protect Against Human Rights Violations Committed Abroad by Transnational Corporations and their Subsidiaries' in Derrick M Nault and Shawn L England (eds.), Globalisation and Human Rights in the Developing World (Basingstoke: Palgrave Macmillan, 2011), p. 133.

86 Ibid.

87 Office of the High Commissioner of Human Rights, Guiding Principles on Business and Human Rights, supra note 43, Commentary to Principle 13.

88 Ibid., Parts I and II. See Justine Nolan, 'Refining the Rules of the Game: The Corporate Responsibility to Respect Human Rights', Utrecht Journal of International and European Law, 30: 7-23 (2014), p. 7 . 
actors, and allocating differentiated responsibilities for human rights violations based on the respect, protect and fulfil framework. ${ }^{89}$ The respect, protect and fulfil framework presumes that States are responsible for compliance with human rights standards, and thus, it was not intended as a means of allocating responsibility between various actors. Although drawn from two sources, ${ }^{90}$ the creation of the respect, protect and fulfil framework had the common aim of capturing all forms of State conduct that are necessary to comply with a human right. ${ }^{91}$ The CESCR has subsequently endorsed and applied the framework to give effect to this intention. ${ }^{92}$ Altering the function of the respect, protect and fulfil framework to allocate responsibility between States and nonState actors gives rise to several complications. In light of the framework's intended function, there was no need to clearly delineate between the obligations to respect, protect and fulfil. Conduct within this framework operates on a continuum ${ }^{93}$ and cannot readily be divided into clearly defined categories. ${ }^{94}$ Further, negatively phrased human rights obligations may require positive action to be taken in order to comply with the right. ${ }^{95}$ Therefore, whether action is classified as breaching either the obligation to respect or to protect is likely to depend on how the action is portrayed. For example, in the Urbaser dispute, it was alleged that the concessionaire had failed to adequately invest in the water and sanitation service. ${ }^{96}$ If this had been established, the failure to invest could be seen as a violation of both the obligation to respect and the obligation to protect. By failing to maintain a water supply service, the concessionaire would be preventing the local population from accessing water by its failure

89 Olivier de Schutter, International Human Rights Law: Cases, Material and Commentary (Cambridge: Cambridge University Press, 2010), p. 248.

$90 \quad$ Henry Shue, Basic Rights: Subsistence, Affluence and Us Foreign Policy (Princeton N.J.: Princeton University Press, 1996), p. 52; Asbjørn Eide, The Right to Adequate Food as a Human Right, E/CN.4/Sub.2/1987/23, 7 July 1987.

91 Shue, supra note 9o, p. 52; Eide, supra note 90.

92 This framework was first endorsed in CESCR General Comment No. 12, supra note 9. Most recently, the model has been applied in CESCR, General Comment No. 24: State obligations under the International Covenant on Economic, Social and Cultural Rights in the Context of Business Activities, E/C.12/GC/24, 10 August 2017.

93 Olivier de Schutter, 'Corporations and Economic, Social, and Cultural Rights' in Eibe Riedel, Gilles Giacca, and Christophe Golay (eds.), Economic, Social, and Cultural Rights in International Law: Contemporary Rights in International Law (Oxford: Oxford University Press, 2014), p. 201.

94 Mégret, supra note 10, p. 132; Giacca, Golay, and Riedel, supra note 10, p. 20.

95 Aaron Xavier Fellmeth, Paradigms of International Human Rights Law (Oxford: Oxford University Press, 2016), pp. 222-223; de Schutter, supra note 93, p. 202.

$96 \quad$ Urbaserv. Argentina, para. 36 . 
to act, thereby destroying the host State population's enjoyment of this right. By framing the foreign investor's conduct in this manner, it could be seen as violating the obligation to respect. To remedy this position, the concessionaire would have to take positive steps by investing further in the water supply service, despite the right being formulated in negative terms. This type of positive action could be perceived as being more closely linked to the obligation to protect. On the other hand, the same conduct could be viewed from the perspective that the host State had not taken sufficient action to ensure that the right of the local population to water was not being damaged or destroyed by the concessionaire. If framed in these terms, the insufficient level of investment would be classified as the State's failure to protect the human right to water. In both scenarios the concessionaire had failed to take the same measures to ensure access to water. Based on the distinction drawn by the tribunal in Urbaser, the concessionaire would be liable if this conduct was framed in terms of the obligation to respect. However, if framed in terms of the obligation to protect, the concessionaire would not be responsible under the international human rights law framework. Given that conduct may simultaneously be construed as breaches of either the obligation to respect or protect, the distinction drawn in the Urbaser award between these types of obligations does not provide a workable foundation for allocating responsibility between States and non-State actors for human rights violations.

\subsection{The International Responsibility of a Foreign Investor}

The Urbaser award formulates a binding legal obligation on both States and foreign investors to respect the right to water. For States, the obligation to respect forms part of their pre-existing international obligations in relation to the right to water, which can be given effect to by using the international human rights law framework. However, given the State-based structure of international human rights law, it is not clear how a right holder can enforce the foreign investor's international responsibility.

A human rights obligation is only effective if there is a forum in which the right holder can enforce the right. ${ }^{97}$ If the host State breaches its obligation to respect the right to water, existing human rights mechanisms will be available to the right holder. In general terms, for an individual to claim against a State, it will be necessary to exhaust local remedies, ${ }^{98}$ which usually requires that

\footnotetext{
97 Anne Peters, Beyond Human Rights: The Legal Status of the Individual in International Law, trans. Jonathan Huston (Cambridge: Cambridge University Press, 2016), p. 495.

98 Dinah Shelton, Remedies in International Human Rights Law (Oxford: Oxford University Press, 2015), p. 90.
} 
an action is heard by the domestic courts of the perpetrating State. However, in the event that local remedies fail, or prove to be inadequate, ${ }^{99}$ depending on the circumstances, a claim could be raised before a regional human rights court $^{100}$ or an individual complaint could be lodged with the relevant treaty body (or treaty bodies). ${ }^{101}$ The availability and effectiveness of the remedies available in each fora will vary. Nonetheless, multiple fora exist that can potentially provide some redress for the victims of the human rights violation committed by a host State.

In contrast, there are limited fora in which rights holders can pursue a claim against a foreign investor for breaching the duty to respect the right to water. International bodies, such as regional human rights courts and treaty bodies, are structured so as to only permit claims against States. ${ }^{102}$ Consequently, rights holders can only seek recourse against the foreign investor in domestic courts. The jurisdiction of the domestic court would only extend to human rights that have been implemented at a domestic level by the State. ${ }^{103}$ As some States only permit human rights claims to be brought against public bodies, ${ }^{104}$ the status of the foreign investor may preclude the claim. In the event that domestic remedies against the foreign investor fail, or prove to be inadequate, an independent claim would have to be made against the State for its failure to protect the right to water in accordance with the existing human rights framework. ${ }^{105}$ This claim, based on the failure of the State's judicial processes to remedy the breach, would rely on the same obligation to protect that could have been initially brought against the State for not regulating the acts of the foreign investor. Consequently, by creating a binding obligation on the foreign investor to respect the right to water, but failing to recognize the limited fora in which claims can be commenced from the perspective of the right holder, the tribunal in Urbaser has immediately diminished the effectiveness of conferring international responsibility on the foreign investor.

\footnotetext{
$99 \quad$ Ibid., p. 92.

$100 \quad$ Ibid., p. 67.

101 Ibid., p. 193.

102 Naegele, supra note 27, p. 118; Kriebaum, supra note 38, p. 186; Jean d'Aspremont, Andrè Nollkaemper, Ilias Plakokefalos and Cedric Ryngaert, 'Sharing Responsibility Between Non-State Actors and States in International Law: Introduction', Netherlands International Law Review, 62: 49-67 (2015), p. 55.

103 Peters, supra note 97, p. 503.

104 For example, sections 6 and 7 of The Human Rights Act 1998 (UK) only permit claims against acts of public bodies.

105 See Antônio Augusto Cançado Trindade, The Access of Individuals to International Justice (Oxford: Oxford University Press, 2011), pp. 99-100.
} 
The right holder will need to find the foreign investor responsible in accordance with international law. States can be held responsible in international law when conduct that constitutes a breach of a binding international obligation can be attributed to them. ${ }^{106}$ The circumstances in which conduct will be attributed to a State are governed by the customary international law principles of State responsibility, which are commonly understood as being codified in the Articles on Responsibility of States for Internationally Wrongful Acts (ARSIWA). ${ }^{107}$ This framework relies on secondary rules of international law to attribute conduct to States, whilst any determination regarding violations of binding international legal obligations is undertaken with reference to the primary laws that create the substantive obligations. ${ }^{108}$ ARSIWA does permit corporate conduct to be attributed to the State, ${ }^{109}$ but there is no equivalent law to ARSIWA that addresses the international responsibility of corporations. ${ }^{110}$ Although ARSIWA is not directly applicable to foreign investors, it could be argued to apply by way of analogy. As the Urbaser award confers a directly binding obligation to respect the human right to water on foreign investors, it is arguable that they are conferred with limited international legal personality, coterminous with this obligation. ${ }^{111}$ If international legal personality is understood as functioning in this way, this may permit the principles of ARSIWA to be translated to address corporate conduct where a directly binding human rights obligation exists. ${ }^{12}$ However, at this point, this conclusion remains speculative. Guidance could also be drawn with other fields of international law. The only other field of international law where non-state actors can be found responsible is in the context of international criminal law. Given the seriousness of international crimes, and the different objectives of this regime, it is unlikely that principles governing responsibility in international criminal law would translate to the context of foreign investors breaching their obligation to respect the right to water. Thus, it remains unclear to what extent principles that attribute conduct to States, or principles used to confer responsibility in

106 International Law Commission (ILC), Articles on Responsibility of States for Internationally Wrongful Acts A/56/10, Article 2 (hereinafter ILC, ARSIWA).

107 ILC, ARSIWA, supra note 106, General Commentary, para. 1; James Crawford, State Responsibility: The General Part (Cambridge: Cambridge University Press, 2013), p. 43.

108 ILC, ARSIWA, supra note 106, General Commentary, para. 1.

109 See CESCR, General Comment No. 24, supra note 92, para. 11.

110 James Crawford and Simon Olleson, 'The Character and Forms of International Responsibility' in Malcolm Evans (ed.), International Law (Oxford: Oxford University Press, 2014), p. 445 .

111 Karavias, supra note 40, pp. 100-102.

112 Ibid., p. 102. 
international criminal law, could be translated to situations where foreign investors have breached their duty to respect the human right to water. ${ }^{113}$ Consequently, the circumstances in which a foreign investor could be found responsible for violating the duty to respect the right to water are currently unknown.

This section, so far, has presumed that the foreign investor will be held solely responsible for a breach of the duty to respect the right to water. However, it is possible that a foreign investor's conduct may breach the obligation to respect the right to water as a result of the host State's failure to adequately protect this right, giving rise to shared responsibility (and potential dual liability). ${ }^{114}$ For example, a foreign investor could fail to respect the right to water because the host State has neglected to protect the right by not including a human rights clause in the concession contract (or has not given effect to the right to water in its domestic legal provisions). Should both actors be found liable for their respective breaches, responsibility would need to be apportioned between the parties. It is unclear what principles would form the foundation for any apportionment between a State and a non-State actor for human rights violations on the international legal plane. ${ }^{115}$ How responsibility is allocated may, in part, depend on the legal principles used to find the foreign investor responsible in the first place. Should ARSIWA be capable of being translated to corporate bodies, concepts such as aiding and abetting, found in Article 16 ARsIwA may prove useful. ${ }^{116}$ However, this would require a significant contribution to the breach by the foreign investor. ${ }^{117}$ Whether this could be established would depend on the facts of each claim. Nevertheless, the potential application of ARSIWA presumes that the claims against the foreign investor and the host State would be heard in the same forum. As two separate claims will have been made against the foreign investor and the State, these may be heard in different fora. Therefore, two separate decision-making bodies may have to independently make this determination. ${ }^{118}$ Consequently, there is the potential for fragmented and inconsistent decision-making. ${ }^{119}$ This could undermine the

113 See d'Aspremont, Nollkaemper, Plakokefalos and Ryngaert, supra note 102, p. 61.

114 See André Nollkaemper and Dov Jacobs, 'Shared Responsibility in International Law: A Conceptual Framework', Michigan Journal of International Law, 34/2: 359-438 (2013).

115 See d'Aspremont, Nollkaemper, Plakokefalos and Ryngaert, supra note 102, p. 55.

116 Karavias, supra note 40, pp. 102-103; James D. Fry, 'Attribution of Responsibility' in André Nollkaemper, Ilias Plakokefalos and Jessica Schechinger (eds) Principles of Shared Responsibility in International Law: an Appraisal of the State of the Art (Cambridge: Cambridge University Press, 2014) pp. 116-117.

117 Karavias, supra note 40, p. 103.

118 Ibid., p. 105.

119 Ibid., p. 107. 
process of allocating responsibility between the parties, and if claims are not co-ordinated, might give rise to additional disputes regarding how to resolve conflicting decisions regarding the apportionment of responsibility. ${ }^{120}$

All of the factors identified above generate multiple variables that those seeking redress for a human rights violation will need to navigate. Given the severe consequences of any violation of the right to water, there is the need for an effective remedy. ${ }^{121}$ By introducing a new actor into State-based human rights structures, the Urbaser tribunal has overcomplicated the processes of determining responsibility for violations of the right to water, which in turn, may preclude victims of human rights violations from being able to access a fast and effective remedy.

\subsection{Preliminary Conclusion}

The tribunal in Urbaser distinguishes between the obligations to respect and to protect in relation to the right to water and allocates responsibilities to States and foreign investors accordingly. Using the respect, protect and fulfil framework to assign responsibility for human rights is problematic as this framework was not intended to perform this function and does not permit the actions of States and non-State actors to be easily categorized. Further, seeking to enforce the duty to respect the right to water against a foreign investor creates difficulties for the right holder. They must identify an appropriate forum in which to bring a claim, determine the legal foundations for assigning responsibility to the foreign investor and resolve potential issues of shared responsibility and dual liability. By creating these legal challenges, the Urbaser award means that right holders are less likely to be granted a remedy in a timely manner. In short, introducing this binding human rights obligation overcomplicates the task of allocating responsibility for the right to water when water supply services have been privatized and are operated by foreign investors.

\section{5}

\section{Conclusion}

The process of privatization produces a variety of interactions between public and private interests. In the context of water supply and sanitation services, understandings of public and private focus on the actors involved, how water

\footnotetext{
120 See d'Aspremont, Nollkaemper, Plakokefalos and Ryngaert, supra note 102, p. 59; André Nollkaemper, 'Concerted Adjudication in Cases of Shared Responsibility', New York University Journal of International Law and Politics, 46/3: 809-847 (2014).

121 CESCR, General Comment No. 15, supra note 6, para. 55 .
} 
should be distributed and how public and private interests are protected by the law. These frames of reference assist in analyzing the reasoning of the tribunal in the Urbaser award. When considering Argentina's counterclaim, the tribunal in Urbaser merged public and private interests when addressing the obligation to respect the right to water. In contrast, when examining the duty to protect the right to water, the tribunal clearly separated these three conceptions of public and private. The result of this approach is that, in relation to the obligation to respect the right to water, both States and foreign investors can be held responsible under international law. The international duty to protect the right to water remains solely an obligation of the State.

Creating differentiated responsibilities between States and non-State actors by drawing upon the respect, protect and fulfil framework in this manner does not align with its intended purpose. Further, the respect, protect and fulfil framework lacks sufficient clarity to perform this function. Additional complications arise when trying to hold a foreign investor responsible in the Statebased human rights framework. In particular, rights holders face challenges identifying an appropriate forum for the claim, determining on what basis foreign investors are to be held responsible and addressing how issues of shared responsibility and dual liability should be co-ordinated. As a result, the right to water becomes vulnerable to legal manoeuvring by those seeking to avoid or minimise liability. These factors combine to reduce the chances of rights holders being able to access a prompt and effective remedy for any violations of the right to water, which undermines the significance of the right.

In sum, for those seeking to impose international responsibilities on corporate bodies for human rights abuses, the Urbaser award may initially appear to be a step in the right direction. However, by attempting to introduce liability for non-State actors within the State-based respect, protect and fulfil framework, the tribunal has blurred boundaries that the human rights regime cannot accommodate at present. Therefore, either international human rights must be solely viewed as State obligations that encompass the duties to respect, protect and fulfil, or alternatively, a new human rights structure needs to be adopted to accommodate non-State actors. The Urbaser award sits uncomfortably between these models and, as a result, confuses the allocation of responsibility for the human right to water. Thus, any symbolic value associated with the Urbaser award being the first to create binding human rights obligations for foreign investors is tainted by the legal uncertainty that results. 